of the last group $6.7 \%$. The difference between these two groups is $13.2 \%$, but its error amounts to $9.1 \%$. Therefore this difference of frequencies of occurrence is very uncertain. The theory of probabilities proves that we might expect these results to be fundamentally changed if the number of observations were increased. In the instance given here the differences of observed values are great; in most cases they are entirely inside the limits of errors. We hold, therefore, that Lombroso has not succeeded in establishing the validity of any of the characteristics of the criminal type which he claims to have discovered.

It is true that signs of degeneracy are frequent among criminals and that a correlation of degeneracy and of criminality exists which may be directly physical, but which is likely to be, to a great extent, social. A consideration of the fact that these signs are not confined to the criminal classes shows that it is an incomplete correlation with which we have to deal. That is to say, signs of degeneracy are sometimes, not always, connected with criminality and, vice versa, criminality is sometimes, not always, connected with degeneracy. Therefore the problem, in order to be satisfactorily solved, should be treated in a manner differing from that applied by Lombroso. Setting aside the necessity of basing descriptions on much more extensive series which would enable us to prove that differences are not merely accidental, both aspects of the correlation should be investigated. We must not only gain systematic knowledge of the characteristics of the criminal classes, but also of the general distribution of each of these characteristics among a variety of classes not criminal. Only in this manner can we hope to understand their significance.

While Lombroso will always deserve the credit of having forcibly called attention to the physical and psychical characteristics of abnormal man, his statistical methods are so unsatisfactory that very few of his results can claim to be well established, and I believe hardly a single one in the volume under review can be considered as proved by the material offered.

Columbis University.

Franz Boas.

\title{
CHILD PSYCHOLOGY.
}

Paidologie. Entwurf zu einer Wissenchaft des Kindes. Oscar Chrisman, In Diss., Jena, 1896. Pp. $72+24$ pages of bibliography.

This is a sketch of 'Paidology' by the original inventor of the term. The introduction is a general plea for the recognition of pai- 
dology as a university study. The author would have it pursued as a pure science and wants everything relating in any way to children to be included in the work, whether it has any practical bearing or not. The short History of Paidology, which follows, consist mainly of mere names and titles of works, but gives no statement of results or summary of ideas contained in the authorities quoted. Everything is made to seem equally valuable.

The system of Paidology is sketched as follows:

1. The Child in History. (The Child among uncivilized and half-civilized peoples.

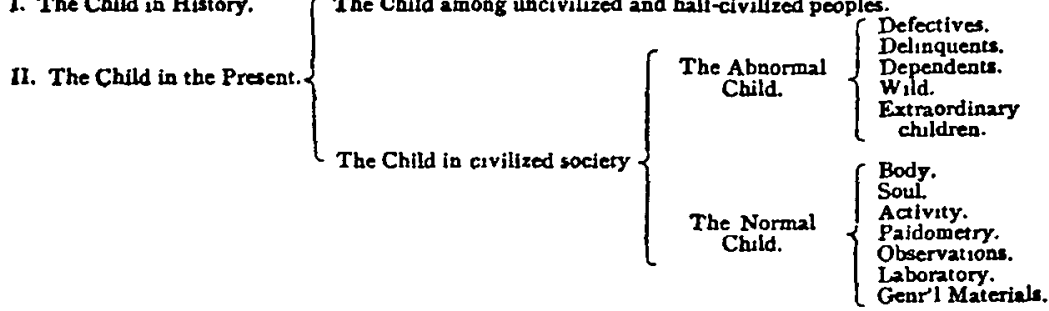

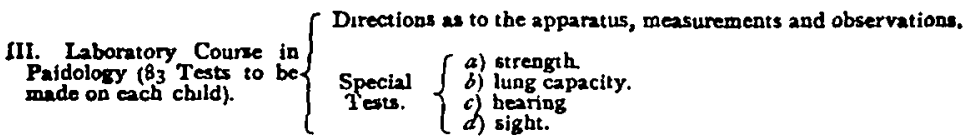

The laboratory course consists of the usual tests of experimental psychology. Certainly the most valuable part of the pamphlet is the list of 522 books and articles relating to children and catalogued in the appendix.

Herman T. Lukrins.

L'instinct de la conservation chez les enfants. PAOLA LomBroso.

Revue Philosophique, Oct., 1896. Pp. 379-390.

Children may be compared to the little infusorian animalculx which are all the more tenacious of life the more microscopic they are. As if conscious of the fragile character of their existence, they maintain their grip with all their force. This is seen as follows :

1. In the physiological development of children. Their respiration, circulation and changes in tissues are more rapid, and, in proportion to their size, they eat twice as much as adults. Like savages, they are less sensitive to physical pain than civilized man, and their wounds heal more easily and more quickly. In fact, children of less than two or three years can seldom locate a pain definitely, and their attention is readily diverted from it.

This innate tendency to the protection of their ego characterizes as well their whole psychic life; and, since effort consumes tissue 
and produces fatigue, children may be said to follow the law of economy of effort, which, in subordination to the law of self-protection, is the great law of psychic life in childhood.

2. In learning language children adopt those forms easiest to them, using instinctively gestures before words and, later, imitating the sounds of objects in onomatopœesis, which is itself a sort of oral gesture. The so-called generalizations of children and their sometimes striking association of ideas are all owing to the repugnance on their part to making the effort necessary in using new terms. To keep applying old terms to new objects is often easier than to learn new words, and hence children continue using the same word for objects, sometimes the most disparate, which however have happened in their mind to be associated in some far-fetched way.

3. In all his conceptions and thinking the child tends to economy of effort. His ideas and images are concrete, because the concrete is easier to grasp than the abstract. He repels instinctively the idea of infinity and immortality, because these require too much effort in thinking them. For the same reason he hates innovations, likes to hear the same story over and over again without the change of a single phrase, and must be put to bed with the same ceremony every night. This ' misoneism' is very serviceable to the child in helping to establish habits of routine and to give a certain settled equilibrium to his ideas.

4. The sensibilities and feelings, when excited, are still more wasteful of vital energy, and here too the children tend to conserve their strength. They are 'myopic to pain and presbyopic to pleasure.' Anything may serve them as a plaything and the most commonplace happenings of their everyday life may delight them. Their imagination turns reality into a romance and, since wishes do become horses, beggars may ride. But the joys and sorrows of childhood are only skin deep, and the caresses and jealousies of children are often only an exaggerated mimicry of the affections. The tendency of childhood, therefore, is, not to love, but to be loved; because this gives pleasure and protection; while, on the other hand, to sympathize with others and share their joys and sorrows would consume vital energy.

5. Hence the young child is scarcely susceptible to real love at all. That this is true is shown by the rarity of cases in which children fall in love, e. g., Berlioz at eight years, Rousseau at eleven, and Marie Baskirtseff at twelve. These exceptions to the rule serve only to show what an enormous expenditure of nervous energy accom- 
panies the presence of deep passion and how important it is that children should be preserved from it, as, indeed, they usually are by the very superficiality of their affectionateness.

6. Even the moral sense is subject to the 'law of the least effort.' A child is naturally prone to resentment, readily lies, easily becomes conceited, and thinks the whole world was made for him. In morals he is essentially an egotist, but gradually puts himself into accord with us and learns to respect the rights of others, because he receives more caresses and bonbons by so doing.

In a word, the same 'law of least effort' that governs all the phenomena of sociology and psychology necessarily governs all the phenomena of child life likewise. Before birth, the fœtus, like a parasite, draws off to itself from its hostess all the materials it needs for its growth and development, utilizing all the maternal organism, blood, respiration, and everything to its own advantage without giving anything in return. The selfishness of the young child is but a continuation of the same process of unconscious parasitic assimilation of its environment.

Bryn Mawr College, Penna.

Herman T. LukENS.

\section{PHYSIOLOGY AND BIOLOGY.}

An American Text-book of Physiology. Edited by WiLlnam $\mathrm{H}$. Howel L. Philadelphia, W. B. Saunders, 1896. Pp. 1052. $\$ 6.00$.

A standard text-book of physiology is, perhaps, more important for the student of psychology than a handbook of psychology. Each of us must form his own apperceptive system of psychology based on data gathered from many sides, but physiology is essential to us, and here we are, to a certain extent, dependent on compilations. We have been fortunate in having such excellent works as Foster's 7 ext Book and Hermann's Handbuch. Foster has an extraordinary insight into the essential bearings of physiological research and great ability as an expositor. For purpose of reference, however, his book is defective, because it gives no references and not sufficient facts. Hermann's Handbuch dates from 1879 , and the intervening years have witnessed great progress in physiology. There is consequently room for a new text-book useful to the psychologist.

The work before us is called an American Text-book, which may be taken to indicate that it is written by American authors and per- 